\author{
ПРОЦЕС ФОРМУВАННЯ ПРОФЕСІЙНИХ ЗНАНЬ, УМІНЬ, НАВИЧОК \\ І МОТИВАЦІЇ У ХОДІ САМОСТІЙНИХ ЗАНЯТЬ ФІЗИЧНИМ ВИХОВАННЯМ \\ I СПОРТОМ СТУДЕНТІВ ВИШУ
}

\title{
THE PROCESS OF FORMATION OF PROFESSIONAL KNOWLEDGE, SKILLS, ABILITIES AND MOTIVATION IN THE COURSE OF SELF-STUDIES OF PHYSICAL EDUCATION AND SPORTS OF UNIVERSITY STUDENTS
}

УДК 378.016:796.011.3

DOI https://doi.org/10.32843/2663-

$6085 / 2020 / 27.11$

\section{Борщов С.М.,}

доцент кафредри теоретичних, методичних основ фрізичного виховання і реабілітації ДВНЗ «Донбаський державний педагогічний університет»

\section{Іванченко Л.П.,}

доцент каредри теоретичних, методичних основ фрізичного виховання і реабілітації

ДВНЗ «Донбаський державний педагогічний університет»

\section{Мельник I.M.,}

старший викладач кафедри фізичної терапії, фрізичного виховання і біології ДВНЗ «Донбаський державний педагогічний університет»
Однією із проблем сучасної системи вищої освіти в Україні є пошук новітніх шляхів підготовки висококваліфікованих спеціалістів у галузі фрізичного виховання і спорту. У зв'язку з цим адаптація фрахівців до нових умов праці вимагає від них глибоких профеесійних знань, умінь, навичок до співпраці, стійкої мотивації, працездатності, здоров'я, якості при формуванні й оволодінні навчальними програмами.

Заняття з фізичного виховання і спорту у виші є однією з основних форм організації студентів. Самостійна робота студентів - важлива складова частина навчального прочесу, в ході якої здійснюється фрормування знань, умінь і навичок і забезпечується засвоєння студентом прийомів пізнавальної діяльності, інтерес до творчої роботи та здатність вирішувати технічні наукові завдання.

Важливою умовою формування позитивної мотивації є визначення чіннісних орієнтирів студента, вибір на чій основі особистісно-значимого, конкретного, цікавого для студентів навчального матеріалу, який сприяє виробленню в них моральної впевненості у ході самостійних занять фрізичним вихованням і спортом.

У процесі експериментальної роботи було доведено, що формуванню професійних знань, вмінь, навичок і мотивації до самостійних занять сприяє дотримання таких педагогічних умов, як: фрормування активного і позитивного ставлення до занять фрізичними вправами; використання спеціальних технічних (тренажерних) засобів у процесі самостійних занять; оволодіння засобом спеціально-оздоровчої направленості; прищеплення знань, умінь і навичок оволодіння методиками та системами оздоровлення.

Отримані результати дають підставу вважати, що теоретичне обгрунтування і практичне втілення в життя основних положень цієї роботи сприятиме удосконаленню фрізичного виховання студентів вишу і фоормуванню в них навичок здорового способу життя.
Ключові слова: професійні знання, мотивація, практична діяльність, самостійні заняття, анкета-інтерв'ю.

One of the problems of the current system of higher education in Ukraine is the development of highly-qualified specialists in the field of physical education and sports. Consequently the adaptation of specialiststonewworking conditions requires deep professional knowledge, skills and abilities to the cooperation, strong motivation, efficiency, health, and quality in the formation and mastering of educational programs. An important condition for the formation of positive motivation is the determination of student's helpful guidance, the choice of personally significant things on this basis, interesting educational material for students that promotes and deepens the development of moral confidence during selfstudies of physical education and sports.

Classes in physical education and sports at the university are one of the main forms of student organization. Independent work of students is one of the most important components of the educational process, during which the formation of knowledge, skills and abilities and further ensures the student's mastery of cognitive techniques, interest in creative work and finally the ability to solve technical scientific problems. In the process of experimental work it is proved that the formation of professional knowledge, skills, abilities and motivation for self-education contributes to the observance of such pedagogical conditions as: the formation of an active and positive attitude to physical exercises; use of special technical (training) tools in the process of self-study; mastering the means of special health-improving orientation; instilling knowledge, skills and abilities to master the techniques and systems of rehabilitation.

The obtained results give grounds to believe that the theoretical substantiation and practical implementation of the main provisions of this work will contribute to the improvement of physical education of university students and the formation of their healthy lifestyle skills.

Key words: professional studies, motivation, practical activities, self-studies, questionnaireinterview.
Постановка проблеми у загальному вигляді. Заняття 3 фізичного виховання і спорту у виші $€$ однією 3 основних форм організації студентів. Самостійна робота студентів - важлива складова частина навчального процесу, в ході якої здійснюється фрормування знань, умінь і навичок і забезпечується засвоєння студентом при- йомів пізнавальної діяльності, інтерес до творчої роботи та здатність вирішувати технічні наукові завдання, про що свідчать науково-методичні роботи В.І. Філінкова, В.Г. Григоренка, Б.М. Шияна, В.І. Мудрік, В.С. Язловецького [7].

Під час виконання самостійної роботи студент повинен вчитися мислити, аналізувати, врахову- 
вати умови, ставити завдання, вирішувати проблеми, тобто сам «процес» поступово повинен перетворюватися у творчий. Фахівець, який відтворює цей процес, логічно ставить такі завдання:

- фрормування розуміння ролі фрізичного виховання і спорту в розвитку особистості та підготовки її до професійної діяльності;

- мотиваційного ставлення до фрізичного виховання і спорту й установка на здоровий спосіб життя;

- фрізичне вдосконалення і самовиховання, потреби в регулярних заняттях фрізичними вправами та спортивною діяльністю;

- фрормування системи знань, умінь і навичок із фрізичного виховання та здорового способу життя;

- зміцнення здоров'я, сприяння правильному та всебічному розвитку організму, профрілактики захворювань і забезпечення високого рівня фрізичного стану та працездатності протягом всього періоду навчання;

- отримання досвіду творчого використання фрізкультурно-оздоровчої та спортивної діяльності для досягнення особистих і професійних цілей.

У цьому процесі можуть допомогти новітні інформаційні технології. Студент із великим інтересом вирішує поставлені завдання, коли використовує сучасний підхід чи сам програмує рішення.

При теоретичному обґрунтуванні було визначено, що процес фрормування професійних знань, умінь і навичок у ході самостійних занять фрізичними вправами, розвиток позитивної мотивації студентів буде успішним за дотримання сукупності педагогічних умов: фрормування позитивного ставлення до занять фрізичним вихованням і спортом, цілеспрямованого мотивування та стимулювання фрізкультурної активності, фрормування у студентів фрізкультурного інтересу, оволодіння знаннями про фрізичне виховання та спорт і фрормування вмінь і навичок до самостійних занять фозичними вправами.

Аналіз останніх досліджень і публікацій. Теоретичне обґрунтування літературних джерел, засоби, характеристики, аналіз, структура і технологія фрормування професійних знань, умінь, навичок і мотивації до самостійних занять фрізичним вихованням і спортом студентів вишу важливі у процесі навчання та здобуття майбутньої профресії. На цьому наголошують дослідження Т.Ю. Круцевич, П.Д. Плахтій, Д.В. Бойко, В.Г. Талайзан, В.Г. Арефр'єва, Є. Кошелєва, С.В. Чередниченко, П.Ф. Рибалко, С.В. Гвоздецької (зі співавторами) [1; 4-6; 8].

У фрормуванні у студентів стійкої мотивації до занять фрізичним вихованням і спортом важливу роль відіграє озброєння їх знаннями, на основі яких фрормується свідоме ставлення до фрізичної культури.
Вивчення досвіду вишу показує, що лише деякі викладачі фрізичного виховання прагнуть фрормувати у студентів стійкі мотиви до занять фрізичною культурою. 3 цією метою окремі педагоги виховують у студентів самостійність, використовуючи при виконанні фрізичних вправ такі методичні прийоми, як оцінювання студентами один одного, самостійне проведення підготовчої та основної частини, використання карток із записами техніки та методики виконання вправ для навчання, правильного підбору вправ при виконанні того чи іншого технічного прийому, створення змагальної ситуації при проведенні структури заняття, періодичне проведення спортивних інформаційних бесід на заняттях у вступній частині, використання інших студентів як «демонстрантів» і помічників, здійснення контролю за виконанням рухових дій [3].

Виділення не вирішених раніше частин загальної проблеми. Новітні зміни у сфері освіти вимагають пошуку нових шляхів розвитку особистості студентів, найбільш повного розкриття їхнього творчого потенціалу.

Нами встановлено, що на активність студентів великий вплив має психологічний клімат, громадська думка та стиль педагогічного керівництва навчальної діяльності.

Таким чином, високий рівень знань у фрізичному вихованні в ході проведення самостійних занять $€$ емоційне задоволення, отримане у зв'язку з цими знаннями і практичною діяльністю, яка вказує на те, що у студентів фрормується інтерес до занять фрізичними вправами та накопичуються профресійні знання, уміння і навички.

Формування профресійних знань, умінь і навичок та розвиток позитивної мотивації відбувається лише тоді, коли на заняттях викладач не «передає» студентам знання, а фрормує у них уміння та потребу вчитися, навчає планувати й організовувати самостійну діяльність, прогнозувати результати цієї діяльності й оцінювати ії̈ об'єктивно згідно 3 вимогами та критеріями. Проблеми полягали в пошуку у процесі фрізичного виховання студентів одних із пріоритетних напрямів професійних знань, умінь, навичок і стійкої мотивації до самостійних занять майбутніх фрахівців із фрізичного виховання та спорту.

Мета статті - з'ясувати процес фрормування професійних знань, умінь і навиків під час самостійних занять фрізичним вихованням і спортом студентів вишу. 3 вирішенням цих питань ми пов'язуємо подальше вдосконалення навального процесу, діяльності з активізації навчання студентів за умов демократизації суспільства.

Виклад основного матеріалу. Наше дослідження проведено з тридцятьма студентами (юнаками та дівчатами) ДВН3 «Донбаський державний педагогічний університет» фракультету фрізичного 
виховання, які відвідували заняття зі спортивнопедагогічних дисциплін 2-3 рази на тиждень (гімнастику 3 методикою навчання, спортивні ігри 3 методикою навчання ) віком 19-20 років. Була започаткована шкала при анкетуванні (2 - у більшості, 1 - у половини, 0 - у невеликої частини).

На початку дослідження було проведено спостереження за ходом занять із додержанням структури занять, де було вирішено основні питання освітніх, виховних і оздоровчих завдань та інтересу до занять. 3 метою визначення функціонального стану студентів до занять фрізичним вихованням і спортом було проведено анкетування за тридцятьма питаннями, що стосувалися формування професійних знань, умінь, навиків і мотивації до самостійних занять фрізичним вихованням і спортом.

Вивчення спеціальної та методичної літератури та власні педагогічні спостереження свідчать про те, що теоретичні відомості про фрізичне виховання і спорт, гігієну і фрізіологію людини у виші повідомляються регулярно, але багато студентів не на високому рівні володіють спортивною термінологією, знаннями про руховий режим, індивідуальний підхід у розробці комплексів ЗРВ, особливості самостійних занять фрізичними вправами та їхнє значення у фрормуванні життєво важливих рухових навичок. Недостатність у студентів знань, вмінь і навиків професійного характеру є одним із найбільш слабких місць у підготовці майбутнього фрахівця.

У роботі щодо фрормування у студентів стійкої мотивації до занять фрізичним вихованням і спорту важливу роль відіграє озброєння їх знаннями, на основі яких фрормується свідоме ставлення до фрізичної культури.

Студенти у загальних рисах знають про позитивний вплив занять фрізичним вихованням і спортом на організм, але мотивація до занять фрізичним вихованням сорормована лише в невеликої кількості студентів. Так, за результатами анкетних даних, систематично фрізичним вихованням вдома займаються лише 23,3\% юнаків і 20\% дівчат, щоденно виконують ранкову гігієнічну гімнастику лише $15 \%$ юнаків і 25\% дівчат.

У дослідженнях встановлено причини, що заважають займатися фрізичним вихованням вдома. На брак часу посилаються 25\% юнаків і 28\% дівчат, відсутність інтересу визначили 6,6\% юнаків і 13,3\% дівчат, не знають, як займатися і потребують допомоги в організації та проведення самостійних занять вдома 20\% юнаків і 17\% дівчат. 3'ясовано, що на брак часу вказують переважно ті студенти, які не вміють правильно спланувати свій день, не мають навичок складання і не дотримуються правильно спланованого режиму дня.

На питання «Чи подобається тобі твоя фрігура?» 43\% юнаків і 40\% дівчат відповіли ствердно. «Не подобається» - 50\% юнаків і 55\% дівчат. Не відпо- віли на питання 7\% юнаків і 5\% дівчат. Поліпшити фрігуру за допомогою фрізичних вправ хотіли 50\% студентів. Таким чином, можна побачити суперечності у відповідях студентів. Недостатньо займаються фрізичним вихованням майже 60\% юнаків цього віку та 56\% дівчат, котрі хотіли б поліпшити фрігуру за допомогою фрізичної діяльності.

Дослідження показало, що велика кількість студентської молоді має слабкий імунітет до застудних захворювань. Так, жодного разу в минулому навчальному році не хворіли лише 10-12\% студентів, 1-2 рази - 50-60\%, 3-4 рази - 6\%, 5 і більше разів - 40-50\%.

Під час навчання у виші педагогічний процес із фрізичного виховання і спорту викладачі повинні спрямувати так, щоб студенти сприймали заняття як засіб підготовки до майбутньої професійної діяльності. На питання «Як Ви вважаєте, чи потрібні заняття фрізичним вихованням для вашої майбутньої профресії?» 80\% юнаків і 75\% дівчат відповіли позитивно.

У ході дослідження встановлено причини негативного ставлення деяких студенів до занять фрізичним вихованням і спортом.

На недостатнє матеріально-технічне забезпечення занять посилаються 16,6\% юнаків і 20\% дівчат. На недостатню вимогливість до відвідування занять - 6,6\% юнаків і 23,3\% дівчат. Брак часу відзначили 6,6\% юнаків і 20\% дівчат. Відсутність інтерес до занять - 10\% юнаків, 13,3\% дівчат. На особисту недисциплінованість вказують 20\% юнаків і 26\% дівчат.

Для визначення взаємозв'язку фрізкультурноспортивної та інших видів діяльності були запропоновані групи запитань:

а) про перевагу виду діяльності в години дозвілля;

б) про вибір однієї із фрорм проведення дозвілля із запропонованих;

в) про вибір одного виду діяльності із двох, одним із яких є орізкультурно-спортивне.

Аналіз відповідей респондентів у першій групі питань показав, що у вільний час студенти віддають перевагу культурним розвагам (60\% юнаків і 46\% дівчат), фрізкультурно-спортивній діяльності 23,3\% юнаків і 6,6\% дівчат, навчальній діяльності 50\% юнаків і 63,3\% дівчат.

Відповіді із другої групи питань загалом збігаються із попередніми даними.

Культурним розвагам надають перевагу 60\% юнаків і 46,6\% дівчат, домашнім фрормам проведення дозвілля - 20\% юнаків і 13,3\% дівчат, заняттям фрізичною культурою і спортом - 30\% юнаків і 23\% дівчат, відновлювальним засобам у процесі спортивних занять - 33,3\% юнаків і 26,6\% дівчат.

На питання: «Чи присутня мотивація в процесі занять фрізичним вихованням і спортом?» ствердно відповіли 60\% юнаків і 40\% дівчат. 
На питання «Що є поштовхом для занять фрізичним вихованням і спортом?» студенти вибрали один із компонентів «зміцнення здоров'я», «зниження маси тіла», «поліпшення фрізичної готовності», «виклик самому собі», «покращення самопочуття» $-50 \%$ юнаків, 30\% дівчат.

Визначаючи засоби спеціально-оздоровчої направленості, респонденти віддають перевагу «оздоровчому бігу», «оздоровчій ходьбі», «плаванню», «ходьбі на лижах», «їзді на велосипеді», «стрибкам зі скакалкою», «гімнастиці», «туризму», «іграм» $-46,6 \%$ юнаків і 30\% дівчат.

На питання «Якими методиками чи системами оздоровчої направленості» обрали самостійні заняття 16\% юнаків, 20\% дівчат. Внаслідок опитування сорормувалася стійка потреба до самостійних занять у $33,3 \%$ юнаків і $43,4 \%$ дівчат. У ході проведення опитування респонденти обирали більш прийнятний підхід до самостійних занять (структуру занять, комплексний підхід, систему занять, фрорму занять, індивідуальні заняття, заняття у групі). Відповіді такі: 43,3\% юнаків і 53,3\% дівчат. На питання: «Чи контролюєте ви хід самостійних занять?» відповіли ствердно 50\% юнаків, $50 \%$ дівчат. Одним із головних компонентів занять $€$ «навантаження» в ході самостійних занять, це питання юнаки оцінили $60 \%$ дівчата - 53,3\%.

Потреба до самостійних занять фрізичним вихованням і спортом може бути сформована лише за комплексного, системного підходу до вирішення цього питання, цілеспрямованого і диференційованого використання всіх об'єктивних і суб'єктивних факторів впливу на особистість.

Висновки. Проведений аналіз і узагальнення науково-методичної літератури виявив у процесі фрізичного виховання і спорту студентів одним із головних напрямів формування профресійних знань, умінь і навиків та стійкої мотивації до самостійних занять.

Процес формування позитивної мотивації є вирішенням і вивченням ціннісних орієнтирів кожного студента і вибір на цій основі особисто-значимого і цікавого для студентів навчального матеріалу.

Формування позитивного ставлення до фрізичних вправ у ході навчальних занять підвищується при засвоєнні не окремих розрізнених знань про значення фізичних вправ, а цілісної системи в тісній єдності з особисто значимими знаннями фрізичного виховання і спорту.

Використання спеціальних тренувальних засобів, оздоровчих систем і методик у процесі самостійних занять стало важливою умовою у процесі проведення регулярного комплексного контролю 3 метою визначення позитивних зрушень в організмі.

Проведення анкетування свідчить, що 50\% респондентів (юнаки і дівчата) вважають необхідними та потрібними заняття з фізичного виховання і спорту для підготовки до майбутньої професії. Слід зазначити, що при дослідженні мотиваційної сорери студентів у процесі занять фрізичним вихованням і спортом, у ході проведення експерименту в них сталися певні зміни (юнаки 60\%, дівчата - 40\%).

Студенти вважають, що існує чітка потреба до самостійних занять у процесі проходження спортивно-педагогічних дисциплін.

У перспективі доречно продовжити дослідження процесу формування профресійних знань, умінь і навиків та мотивації у ході самостійних занять. Потребує подальшого вивчення питання характеру реальних взаємин між студентами, між студентами і викладачами в різних фрормах «фрізкультурної» діяльності.

\section{БІБЛІОГРАФІЧНИЙ СПИСОК:}

1. Арефьєв В.Г. Самостійна робота студентів під час педагогічної практики. Київ : Центр навчальної літератури, 2015. 120 с.

2. Бакіко І. Місце фізичної культури та спорту в дозвіллі молоді. Фізичне виховання, спорт і культура, здоров'я у сучасному суспільстві. № 3 (11). 2016. C. 25-28.

3. Бойко Д.В. Удосконалення фізичного виховання зі спортивної спрямованістю студентів вищих навчальних закладів : автореф. дис. ... канд. наук 3 фіз. вих. і спорту. Львів, 2013. 19 с.

4. Гвоздецька С.В., Чередниченко С.В., Рибалко П.Ф. Професійно-прикладна фізична підготовка : начальний посібник. Суми : ФОП Цьома С.П., 2017. 110 с.

5. Кошелева Е., Турчанников Н. Организационнометодические условия совершенствования системы фризического воспитания студентов. Спортивний вісник. Придніпров'я. № 3. 2016. С. 98-103.

6. Круцевич Т.Ю. Методика фрізичного виховання різних груп населення. Т. 2 Київ : Олімп. література, 2008. C. 167-171.

7. Організаційно-методичні основи фрізичного виховання студентів вищих навчальних закладів / за ред. В.І. Мудріка. Київ : Педагогічна думка, 2010. $192 \mathrm{c}$.

8. Плахтій П.Д., Коваль О.Г., Рябцев С.П., Марчук В.М. Основи фрізичного виховання студентської молоді. Кам'янець-Подольськсий, 2013. 312 с. 